DOI

\title{
МЕТОДИКА МОДЕЛЮВАННЯ ГІПОКСИЧНОГО ЕФЕКТУ АТМОСФЕРИ ПРИ ІІІ ТИПІ ПОГОДИ
}

\section{СН. М. Волкова}

\section{ДВНЗ «Тернопільський державний медичний університет імені І. Я. Горбачевського мОЗ України»}

РЕЗЮМЕ. За даними сучасних наукових розробок, визначення індивідуальної типології адаптаційних реакцій організму з урахуванням міжсистемних функціональних взаємодій $є$ важливим завданням сьогодення. Нами запропоновано і апробовано методику моделювання гіпоксичного ефекту атмосфери, який спостерігається в природних умовах при метеоситуації III типу. Дана методика рекомендується для моделювання і дослідження адаптивних функціональних змін в організмі лабораторних тварин.

КЛЮчОВІ СлОВа: адаптація, гіпоксичний ефект атмосфери, метеоциклон.

При проходженні атмосферного фронту природна динаміка атмосферних процесів веде до змін парціальної щільності кисню в атмосферному повітрі, що може набирати характеру погодної аномалії - гіпоксичного ефекту атмосфери при метеоциклоні [1], який викликає в організмі людини суттєві зміни центральної регуляції автономних функцій, що характеризуються в літературі як метеотропні реакції [2]. Гіпоксичний тип погоди виступає причиною поганого самопочуття, сонливості, зниженої працездатності [3]. Дані про несприятливий вплив певних метеоумов і типів погоди на здоров'я людини потребують подальшого детального вивчення [4]. 3'ясування детальних механізмів формування реакцій здорових осіб на гіпоксичний ефект атмосфери дозволить об'єктивно оцінити індивідуальний характер адаптаційних змін.

За даними сучасних наукових розробок, визначення індивідуальної типології адаптаційних реакцій організму з урахуванням міжсистемних функціональних взаємодій, $є$ важливим завданням сьогодення [5]. Все більшої актуальності набувають проблеми ранньої діагностики і прогнозування порушень здоров'я з урахуванням індивідуальних особливостей стану адаптаційно-компенсаторних механізмів організму. Водночас в літературі $\epsilon$ небагато експериментальних моделей, які 6 дозволяли дослідити дозований вплив несприятливих метеофакторів, зокрема гіпоксичний ефект атмосфери при III типі погоди.

Мета дослідження. Моделювати в експерименті гіпоксичний ефект атмосфери, який спостерігається при III типі погоди.

Матеріал і методи дослідження. Для оцінки метеоситуації застосовували морфодинамічну класифікацію І. І. Григор'єва, І. Г. Парамонова, М. М. Тена [4], яка включає чотири типи погоди. Гіпоксичні метеоумови спостерігали при типі III (несприятлива погода). Цей тип погоди характеризується утворенням циклонів з вираженими фрон- тальними розділами і висхідними вертикальними потоками повітря (фронтальні розділи з наявністю значних контрастів метеоелементів). Відзначаються добре виражені ділянки динамічної зміни атмосферного тиску, середньої та великої сили висотні переміщення повітря. Спостерігаються порушення добового ходу основних метеоелементів. При погоді III типу температура повітря може змінюватися на $10-20^{\circ} \mathrm{C}$ за 6-12 год, відносна вологість - на 20-40\%. Атмосферний тиск змінюється на 3-4 гПа за 3 год. Швидкість вітру може зростати до 10-16 м/с. Вміст кисню коливається на $\pm 15-20$ г на 1 кг повітря. Напруженість атмосферного електричного поля помітно відрізняється від нормальних значень, відзначаються чіткі коливання поля і короткочасні великі і різкі його зміни. Можливі геомагнітні збурення. Цей тип погоди відрізняється іноді різкими коливаннями температури і зниженням відносної вологості повітря при посиленні вітру (фен, бору, місцеві вітри); відзначається «задушлива погода». В окремі дні і періоди погода III типу відрізняється різкою зміною повітряних мас, вираженою перебудовою атмосферних процесів, аномально високими або низькими показниками основних метеоелементів, порівняно з місцевою кліматичною нормою.

Для визначення вмісту кисню в атмосферному повітрі використовували методику В. Ф. Овчарової [6]. 3 метою організації досліджень ідентифікували тип погоди, користуючись даними про хід метеоелементів, отриманими з обласної метеостанції, зокрема обраховували вміст кисню в атмосферному повітрі.

Сатурацію крові визначали методом пульсоксиметрії [7] у практично здоровых охочих, робота яких була пов'язана із розумовою працею: 20 обстежених віком 20-25 років, 20 участників обстеження 35-42 років і 20 осі6 58-72 років. О6стеження проводили у спокої і після виконання тестового розумового навантаження при метеоситуації I і III типу. Тестове розумове навантажен- 
Огляди літератури, оригінальні дослідження, погляд на проблему

ня полягало у виконанні простих арифметичних дій в умовах 50 \% дефіциту часу при мотивації на найкращу швидкість і якість обчислення. Пульсоксиметрія дозволила неінвазивним методом визначити вміст оксигемоглобіну в артеріальній крові у відсотках, що характеризували терміном «сатурація". Занотовували показник сатурації крові киснем з дисплею приладу у спокої і протягом виконання розумового навантаження. Вважали за норму показники в діапазоні 95-99 \% [7].

Упершій серії експериментів досліджували ТБКактивні продукти у мозку і крові щурів усіх вікових груп протягом першої доби формування погодних умов-нормоксичного середовища при І типі погоди і природного гіпоксичного ефекту атмосфери при III типі погоди. У другій серії експериментальних досліджень вплив гіпоксичної атмосфери створювали за допомогою зниження тиску в апараті Комовського. Тривалість гіпоксичного впливу підбирали до появи ультрамікроскопічних ознак пошкодження нейронів асоціативної кори головного мозку щурів. Використання електронномікроскопічного методу дало можливість більш глибоко й детально охарактеризувати структурні компоненти кори великих півкуль в експериментальній групі тварин, які піддавалися модельованому гіпоксичному впливу. Дослідили ультраструктуру пірамідних нейронів кіркової ділянки Ос2L [8].

Експериментальні дослідження проведені на нелінійних щурах обох статей трьох вікових періодів: молодих віком 1-1,5 місяці масою 70-100 г, статевозрілих дорослих віком 6-8 місяців масою 175-230 г і старих віком 10-12 місяців масою 250-350 г. Усього в експериментальних дослідженнях використано 480 тварин. Усіх тварин утримували на стандартному раціоні віварію. Дослідження виконували відповідно до «Загальних етичних принципів експериментів на тваринах", ухвалених Першим національним конгресом 3 біоетики (Київ, 2001) та узгоджених з положеннями «Європейської конвенції щодо захисту хребетних тварин, які використовуються для експериментальних і інших наукових цілей» (Страсбург, 1986). Комісією з біоетики ДВНЗ «Тернопільський державний медичний університет імені І. Я. Горбачевського МОЗ України» порушень моральноетичних норм при проведенні науково-дослідної роботи не виявлено.

Результати й обговорення. Якщо при сприятливих метеоумовах антициклону середній вміст кис-

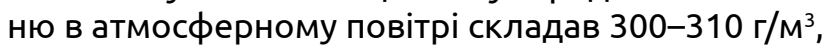
то при III типі погоди, яка характеризується високою циклонічною активністю в атмосфері, за межами приміщення було виявлено вміст кисню в повітрі 279-281 г/м³. Всі дослідження проводили у приміщеннях, де в холодну пору року викори- стовується опалення. Зауважимо, що за місцевих умов III типу погоди відносна вологість повітря дорівнювала 100 \%, яка не зменшувалась у приміщенні за присутності працюючих там людей. Після врахування в обчисленнях температури повітря в кімнаті $20-25^{\circ} \mathrm{C}$ і вологості $100 \%$, вміст кисню в по-

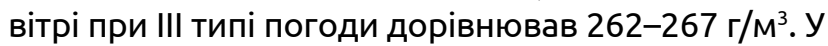
такому разі в кімнаті вміст кисню знизився на 15$18 \%$, порівняно з атмосферними умовами погоди І типу для даної пори року. Вважали, що в опалюваному приміщенні швидкість вітру не впливала, а освітлення відповідало інтенсивності денного світла при I типі погоди; стінами приміщення частково екранувалися природні електромагнітні поля [9]. Таким чином, у наших дослідженнях основну частку впливу чинників погоди складали зміни атмосферного тиску, вологості і залежна від них концентрація кисню у повітрі [4], і при III типі погоди за місцевих метеоумов у робочому приміщенні створювався комплекс несприятливих умов зовнішнього середовища, які чинили гіпоксичний вплив на організм людини.

Дослідження сатурації артеріальної крові киснем за умов метеоциклону при III типі погоди, яке ми здійснили у практично здорових осіб методом пульсоксиметрії, виявило суттєве зниження даного показника у спокої у віковій групі другого періоду дорослості до 95-93 \%. За критеріями В003, сатурація артеріальної крові киснем менше 95 \% створює передумови для гіпоксичного пошкодження тканини мозку [7]. В експерименті, згідно з даними літератури, вміст кисню в навколоклітинному середовищі 94 \% викликає кальцієвий пробій клітинних мембран нейроцитів, що $\epsilon$ початковим етапом гіпоксичного ураження [10]. За даними літератури, клімато-фізіологічні дослідження виявили залежність кисневого забезпечення організму людини від синоптикометеорологічних умов [6].

За нашими даними, при метеоциклоні накопичувалися ТБК-активні продукти у мозку і крові щурів усіх вікових груп, отже гіпоксичний ефект атмосфери при метеоситуації III типу створював пошкоджувальний вплив на клітинному рівні [11].

Гіпобаричне середовище, за умов зниженого атмосферного тиску в експерименті, створювали аналогічно до природних умов III типу погоди. Вплив гіпоксичної атмосфери створювали за допомогою зниження тиску на 50,76 гПа (0,05 атм). Дослідження впливу гіпоксичної атмосфери, яку створювали за допомогою зниження тиску в апараті Комовського і утримування занаркотизованого щура під дзвоном, виявило субмікроскопічні ознаки пошкодження нейронів асоціативної кори великих півкуль після тривалості експерименту протягом 1 год. 
Огляди літератури, оригінальні дослідження, погляд на проблему

Висновки. Запропонована і апробована нами методика моделювання гіпоксичного ефекту атмосфери відображає процеси, які спостерігаються у природних умовах при метеоситуації III типу.
Перспективи подальших досліджень. Дана методика рекомендується для моделювання і дослідження адаптивних функціональних змін в організмі лабораторних тварин.

\section{ЛІТЕРАТУРА}

1. Хаснулин В. И. Роль экологически обусловленного стресса и функциональных асимметрий головного мозга в адаптации и дизадаптации висцеральных систем в экстремальных климато-геофизических условиях Севера (на примере сердечно-сосудистой системы) / В. И. Хаснулин // Современные проблемы общей патологии и экологии человека : труды НЦКЭМ СО РАМН ; под ред. В. П. Казначеева. - Новосибирск : СО РАМН. 2002. - С. 62-70.

2. Агаджанян Н. А. Экология, здоровье, качество жизни (Очерки системного анализа) / Н. А. Агаджанян, Г. П. Ступаков, И. Б. Ушаков. - Москва-Астрахань : Изд-во АГМА, 1996. - 260 с.

3. Деряпа Н. Р. Адаптивные и дизадаптивные изменения основных гомеостатических процессов (биофизических, метаболических, иммунологических, нейроэндокринных) у здорового и больного человека в периоды геофизических возмущений / Н. Р. Деряпа // Роль гравитационных возмущений в солнечной системе в совокупном влиянии погодных и геофизических условий на состояние человека : регионарный симпозиум, 1-3 ноября 1989 г. : тез. докл. - Новосибирск, 1989. - С. 1-5.

4. Ермакова Л. Н. Влияние метеорологических условий на самочувствие человека / Л. Н. Ермакова, Е. С. Ермакова // Географический вестник. - 2012. № 2(21). - С. 45-52.

5. Особенности адаптации жителей Заполярья и возможности коррекции с применением электросна / И. Е. Оранский, Е. И. Лихачева, Н. А. Рослая, Г. В. Талалае- ва // Камчатка - здравница северо-восточных регионов России : межрегиональная научно-практическая конференция, 22-24 октября 2009 г. : материалы и доклады конф. - 2-е изд., доп. - Петропавловск-Камчатский : НИГТЦ ДВО РАН, 2009. - С. 174-179.

6. Овчарова В. Ф. Определение содержания кислорода в атмосферном воздухе на основе метеорологических параметров (давления, температуры, влажности) с целью прогнозирования гипоксического эффекта атмосферы / В. Ф. Овчарова // Вопросы курортологии, физиотерапии и лечебной физкультуры. 1981. - № 2. - С. 29-34.

7. Руководство ВОЗ по пульсоксиметрии. - WHO Press, 2009. $-23 \mathrm{C}$.

8. Волкова Н. М. Характеристика морфо-функціональних особливостей мозку старих щурів залежно від метеоситуації / Н. М. Волкова // Вісник морфології. 2011. - Т. 17, № 3. - С. 526-528.

9. Темурьянц Н. А. Современные представления о механизмах электромагнитных воздействий / Н. А. Темурьянц, А. В. Шехоткин // Вестник физиотерапии и курортологии. - 1999. - № 1. - С. 8-13.

10. Effect of hypoxia on calcium channels depends on extracellular calcium in CA1 hippocampal neurons. / E. Lukyanetz, V. Shkryl, O. Kravchuk, P. Kostyuk // Brain Res. - 2003. - Vol. 980, № 1. - P. 128-134.

11. Волкова Н. М. Стан ПОЛ у мозку і зміни реактивності автономної регуляції кровообігу молодих щурів при метеоциклоні / Н. М. Волкова // Медична хімія.2012. - Т. 14, № 1 (50).- С. 109-113.

\section{METHOD OF MODELING THE EFFECT OF HYPOXIC ATMOSPHERE IDENTICAL TO ADVERSE WEATHER TYPE III}

ON. M. Volkova

\section{SHEI «Ternopil State Medical University by I. Ya. Horbachevsky of MPH of Ukraine»}

SUMMARY. According to modern scientific research, determining individual typology of adaptive reactions based on functional interactions is an important task today. We proposed and tested method of modeling hypoxic atmosphere effect observed in vivo in meteorological III type. This method is recommended for modeling and study of adaptive functional changes in laboratory animals.

KEY WORDS: adaptation, hypoxic effect of the atmosphere, cyclonic weather. 